Н. М. Шарманова

\title{
ДУХОВНИЙ КОД ЯК ЛІНГВОКУЛЬТУРНИЙ ЕТАЛОН НАЦЇ̈ (НА МАТЕРІАЛІ ПАРЕМІЙНИХ КЛІШЕ)
}

\begin{abstract}
Шарманова Н. М. Духовний код як лінгвокультурний еталон нації (на матеріалі паремійних кліше).

Духовні цінності відіграють роль соціокультурних векторів і становлять духовно-етичне ядро нації. Кодування сакральної сфери належить до еталонних виявів світоглядної системи. Духовний код є аксіологізованим кодом, що відображає комплекс моральних цінностей, ідеалів, категорій та еталонів. Лінгвальне вираження духовного коду українства репрезентовано паремійним простором мови. Паремійні кліше як семіотичні знаки транслюють соціокультурні вектори, де сконцентровано прагматичні установки щодо активного світобуття i втілено морально-етичні пріоритети національного світогляду. Пареміологія побудована на бінарних опозиціях задля номінування категорійних протиставлень.

Ключові слова: код культури, духовний код, мовні маркери національної самосвідомості, паремійний простір мови, паремійне кліше, соціокультурний феномен, лінгвокультурний еталон.
\end{abstract}


Шарманова Н. Н. Духовный код как лингвокультурный эталон нации (на материале паремических клише).

Духовные ценности играют роль социокультурных векторов и составляют духовно-этическое ядро нации. Кодирование сакральной сферы принадлежит к эталонным проявлениям мировоззренческой системы. Духовный код является аксиологизированным кодом, раскрывающим комплекс этических ценностей, идеалов, категорий и эталонов. Лингвальное отображение духовного кода украинцев представлено паремическим пространством языка. Паремические клише как семиотические знаки транслируют социокультурные векторы, в которых сконцентрированы прагматические установки активной жизнедеятельности и закреплены морально-этические приоритеты национального мировоззрения. Паремиология построена на бинарных оппозициях для номинации категориальных противопоставлений.

Ключевые слова: код культуры, духовный код, лингвистические маркеры национального самосознания, паремическое пространство языка, паремическое клише, социокультурный феномен, лингвокультурный эталон.

Sharmanova N. M. Spiritual code as a lingua and cultural standard of nation (on the material of paroemic cliché).

Spiritual culture creates a special world of values, forms and complies with human intellectual and sacral demands. Spiritual values become special social and cultural vectors creating moral and spiritual base of national self-identity. Sacred sphere and spirituality encoding refers to the standard expressions of national ideological system. Language area as a coded system of axiological concepts and meanings of decoding reveals a nation's worldview. Deep-seated perception of culture as a semiotic system becomes comprehensible via cultural code. This provides depiction of information transfer, processing, preservation within sign systems that cultural codes are. In the study of codification, spiritual code, which makes for moral values and standards, fixed in language, holds a specific place.

Spiritual code of Ukrainian culture is a value oriented linguistic and philosophical category, which absorbs millennial folk wisdom imperative and philosophical foundations of Ukrainian nation worldview and ideology. Spiritual code represents axiology code that displays a set of moral values, ideals, categories and standards. Verbal expression of Ukrainians' spiritual code is illustrated in idiomatic Ukrainian.

The most powerful complier of the above-mentioned mechanisms is a corpus of precedent phenomena in language and paroemiological clichés in particular. As well as space of universal spiritual culture, the spiritual continuum of Ukrainian heritage always contains the vertical, which was segregating sacredness and commonness, earthly and heavenly life, up and down, good and evil.

Paroemic clichés being semiotic signs broadcast social and cultural vectors of the modern Ukrainian nation. These vectors are focused on pragmatic attitudes to the active society existence and implement moral and ethical outlook priorities of national selfconsciousness and self-identity among the all Ukrainians. The entire paramiology is based on contrast of good and evil. The oppositional technique of logical interdependence upbuilding in paroemias elicits dominance of counterpositions in establishment of native speakers' linguistic consciousness and subconsciousness as it highlights semantic opposition 
of the selected moral and ethical elements. Categories "good" and "evil" as basic representatives of a spiritual code estimate the whole human existence. This very binary opposition gives grounds for nominating categorical oppositions and vectors of Ukrainian nation's spiritual priorities.

Key words: code cultures, spiritual code, verbal markers of national self-identity, paremia idiom stock, paroemic cliché, social and cultural phenomenon, lingua and cultural standard.

Становлення української державності, інтеграція в європейське і світове співтовариство та побудова громадянського суспільства передбачають орієнтацію на пріоритети духовної культури. Духовність $є$ однією 3 найсуттєвіших характеристик людини як особистості, активного суб'єкта людських узаємин. У духовності опосередковано чи безпосередньо виявляються певні особливості ставлення людини до інших, до явищ навколишньої дійсності, до себе самої - до всього, чим вона безперервно, щоденно збагачується упродовж життя. Аналіз окреслених позицій сприяє розумінню досить вагомих змістових ознак особистості, що $\epsilon$ визначальним для репрезентації духовного коду національної культури.

Суспільну цінність, значущість особистості як носія системи соціокультурних маркерів неможливо збагнути, якщо не декодувати сферу iï духовності. Суспільне життя переконує, що без культивування низки моральних цінностей (добро, людяність, відповідальність, почуття власної гідності, толерантність тощо) навряд чи можна розраховувати на покращення соціокультурної ситуації в Україні. Такі властивості людини, як самоусвідомлення себе i свого місця в суспільстві, визначеність світоглядних орієнтацій, здатність орієнтуватися в динаміці навколишнього світу, працьовитість, професійна досконалість і т.ін. не можуть бути об'єктивно оцінені поза контекстом духовності.

Проблема духовності не $є$ новою, вона привертала і продовжує привертати широкі кола дослідників, а саме філософів, філологів, богословів і мистецтвознавців (С. Анисимова, Н. Арутюнової, М. Бахтіна, С. Возняка, С. Воркачова, 3. Коцюби, С. Кримського,

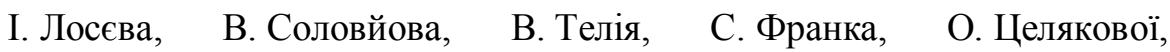
$-83-$

(с) Н. М. Шарманова, 2016. 
I. Шалишкіної, Ж. Юзвак та ін.). У низці наукових розвідок розкрито розмаїття власних підходів щодо усвідомлення феномена духовності в контексті суспільно-історичного розвитку, постановку проблеми, способи іiі розв'язання. Суперечливий характер різних позицій, відсутність єдиного методологічного підгрунтя щодо поняттєвого апарату і цілісного розуміння духовності як загальнокультурного явища спричиняють виокремлення таких напрямків сутності духовності, як культурний, філософський, релігійний [8, с. 31]. Відповідно до цих підходів наявні відмінні тлумачення природи духовності, зумовлені різним осмисленням сутності людини, іiі місця в історії та структурі Універсуму. Крім того, духовність інтерпретовано в лінгвокультурологічних студіях. Спільною, загальнолюдською тенденцією синтезу духовності $\epsilon$ концептуальне освоєння таких вихідних положень, як освоєння екзистенційної картини світу, розширення й лінгвалізація свідомості, самоусвідомлення картини світу i картини життя (Н. Арутюнова), тотожність мікро- і макрокосмосу, регулювання поведінки мовної особистості як складової соціуму за допомогою системи духовних цінностей та ідеалів. У такому розумінні паремійний простір з його безапеляційною прагматикою можна вважати за найвиразніше джерело дослідження духовно-ціннісної царини українців. Відтак вважаємо, що порушена лінгвофілософська проблематика $\epsilon$ актуальною, оскільки вивчення ціннісно-смислового потенціалу в пареміологічній спадщині віддзеркалює не тільки комунікативно-прагматичний, але й екзистенційний досвід людини, опосередкований аксіологічними уявленнями про сутність буття в сучасному соціумі. Наше зацікавлення становить лінгвокультурний аспект духовного коду в паремійних кліше.

Метою нашої роботи $є$ визначення й опис суспільних феноменів-репрезентантів духовного коду української національної культури. Відповідно до мети виділяємо низку дослідницьких завдань: 1) з'ясувати феноменальну природу й репрезентанти духовного коду, 
що виступають ключовими сутностями задля розуміння українського національного менталітету; 2) розкрити морально-етичний потенціал вітчизняної пареміології - духовної площини прецедентних семіотичних знаків як регуляторів моральної поведінки людини в сучасному соціумі; 3) здійснити опис семантичних маркерів структури духовного коду в паремійних кліше.

В основу розгляду проблематики духовного коду етнокультури, власне духовності як лінгвофілософського феномена, покладено функціональний i антропологічний принципи. Лінгвософія інтерпретована тезою про те, що сакральна сфера найвиразніше розкривається в мові як духовному мірилові, на основі якого грунтується розуміння культурного життя народу, його звичаєвого устрою, чуттєвої сфери й мислення, системи ментальних і поведінкових стереотипів. В осмисленні етнокультурної специфіки функціонування української мови провідним є положення О. Потебні про національну мову як першопочаток та підгрунтя національної й етнічної самосвідомості. Мовні явища - це перш за все етнокультурна цілісність й універсальна філософська система символів національного буття.

Антропоцентризм в осмисленні ключових понять відстежується в тому, що суспільна цінність людини є настільки вищою, чим глибше вона осягнула не тільки власні можливості, але й усвідомила необхідність їх утілення в життя, збагнула своє призначення в соціумі. Лише духовно довершена людина 3 усією своєю індивідуальністю здатна відчувати себе складником суспільства, спроможна зрозуміти те, що тільки завдяки творенню добра вона може найповніше реалізуватися й осягнути сенс людського буття. Аксіологічність як одна 3 ключових ознак духовності інтерпретує важливі етичні категорії - добро, істину, красу тощо. «Духовність постає як інтегральна категорія, що виражає теоретико-пізнавальну, художньотворчу та морально-аксіологічну активність людини» [11, с. 224].

Значення духовності стає винятковим нині, коли сьогодення пропонує кожному численну кількість виборів, життєвих самовизначень 
у найрізноманітніших суспільних практиках, сферах людської діяльності i, що не менш важливо, - у виборі ціннісних орієнтирів, які визначають життєвий шлях особистості [3, с. 4]. Саме завдяки цьому процес осмислення культурно-етичних засад розбудови української нації в контексті кодування й репрезентації системи духовних цінностей не втрачає націоцентричної спрямованості, стає підгрунтям у формуванні власне духовного коду вітчизняної етнокультури. До компонентів національної самосвідомості належать традиційна народна духовна й матеріальна культури, професійна національна культура, мова, спільність походження та історичної долі, риси характеру, віра. Вони виступають фактором консолідації нації, входять до системи державотворчих елементів і детермінують самоідентифікацію народу.

В. Калашник слушно зазначає, що «основи національнокультурної самоідентифікації закладаються в ранньому віці разом 3 опануванням рідної мови і в подальшому стають дійовим чинником духовного розвитку особистості. Усвідомлення й розвиток почуття причетності до національної спільноти здійснюється в семіосфері буття нації з іï ціннісними пріоритетами. Важливу роль у цьому повинні відігравати сім'я, система освіти, засоби масової інформації, мистецтво. У своїй сукупній діяльності вони утворюють семантичний простір культури» [5, с. 62], і власне, самі транслюють ті чи ті суспільні репрезентанти духовності.

Споконвіку буття соціуму грунтувалося на моральних i матеріальних цінностях, але основою взаємовідносин та самого життя були духовні цінності: доброта, любов, підтримка, милосердя, щастя.

Духовна цінність - це те, що вище за матеріальні, те, що має бути на першому місці, тобто те, що варте поваги [11]. Їх поділяють на абсолютні, або вічні; національні; громадянські; сімейного життя та особистого життя. Систему духовних цінностей особистості, на думку М. Боришевського, утворює ряд підсистем, а саме: моральні цінності; громадянські цінності; світоглядні цінності; інтелектуальні цінності; естетичні цінності;екологічні цінності [1, с. 24-25]. 
Духовні цінності, що належать національній спільноті та становлять основу ऑiі існування й розвитку, $€$ національними духовними цінностями, які в житті суспільства відіграють роль особливих інтегрувальних засад i, виступаючи у формі ціннісних настанов, орієнтацій, соціально-політичних ідеалів, ідей, утворюють духовно-ціннісне ядро національної самосвідомості.

До основних духовних векторів українства зараховують такі цінності: національна державність, християнська віра, рідна мова. Значущими «для українців є такі цінності: ставлення до землі як до Батьківщини-матері, до своїх культурно-історичних цінностей, толерантність щодо інших культур, релігій; волелюбність; перевага чуттєвого над раціональним (I. Мірчук, М. Шлемкевич, Д. Чижевський)» [9, с. 64].

Пріоритетами в аксіологічній сфері сучасного українського суспільства є духовність, сімейні цінності, свобода, мир і злагода, національно-культурні цінності, патріотизм [11, с. 152-153]. Нині основою національних цінностей постає справедливість, чесність і відповідальність; збереження етнокультурної спадщини; авторитет сумлінної чесної праці й добробут; державна й соціальна безпека, добросусідство, незалежність у відносинах 3 іншими країнами. Патріотизм набув за останні роки виразного громадянського звучання, тому актуалізувалися мовні експоненти духовності, зокрема вислови на зразок Нема у світі, як своя країна (2, с. 169); Свій край, як рай, а чужа країна, як домовина (2, с. 169); У ріднім (рідному) краї $i$ бур'янець пахне (навіть дим солодкий та коханий) (2, с. 166).

В осмисленні окресленої лінгвофілософської категорії значну роль посідають так звані мовні духовні маркери, роль яких можуть виконувати прецедентні висловлення - предикативні або непредикативні завершені й самодостатні одиниці, складні знаки, які неодноразово відтворюються в мовленні носіїв певного лінгвоментального комплексу, певної національної культури та відомі більшості членів конкретної національної лінгвокультурної спільноти 
[6, с. 325]. Прецедентні висловлення належать до таких феноменів, які акумулюють багатовікову мудрість, $є$ продуктами колективної етнічної свідомості носіїв тієї чи тієї мови та виконують роль універсальних семантичних маркерів духовності, як-от: Pecunia (aes) non olet; Гроші не пахнуть (2, с. 89); Деньги не пахнут (2, с. 89).

Необхідним i доцільним $є$ 3'ясування питання про мовне кодування духовності в українській пареміології, яку становлять моральні цінності й еталони, зафіксовані в мові. Одиницею пареміології є паремія, що вирізняється афористичністю, усталеністю, переосмисленим чи буквальним узагальненим значенням, здебільшого повчальним змістом, мовний знак, який передає інформацію про традиційні цінності та погляди, грунтовані на життєвому досвіді народу, позначає типову життєву ситуацію [6, с. 16]. Оскільки духовність пронизує все людське буття, зумовлює поведінку й діяльність, зосереджує увагу на морально-етичних цінностях, то вона потребує комплексного й детального аналізу через призму паремійних кліше.

У системі цінностей української нації як спільноти та усіх етнічних спільнот, що на сьогодні проживають в Україні і вважають іiі своєю Батьківщиною, чільне місце посідають громадянські права i свобода, рівноправність, спільність позицій громадян щодо стратегічних напрямів і мети розвитку держави, узаємна толерантність і соціальна солідарність між різними суспільними групами у процесі міжкультурної комунікації; гордість за Батьківщину, повага до іiі символів та атрибутів, включаючи українську державу; пошана до нації, що утворила державність, національна гідність у поєднанні 3 повагою до всіх етносів. Нині у свідомості жителів усіх регіонів превалює розуміння цінностей громадянського змісту, а саме: праця на благо країни, готовність боротися за державний суверенітет, за дотримання прав і свобод усіх українських громадян, прагнення до європейського співтовариства, рівності прав усіх національностей, знання історії та культури України й плекання в молодого покоління любові до неї [3, с. 5]. 


\section{СТРУКТУРА I СЕМАНТИКА МОВНИХ ОДИНИЦЬ}

Осмислюючи питання історичної долі i правди, витоків української духовності, В. Янів, услід за О. Кульчицьким, цитує думку М. Шлемкевича: «В осередку українського світовідчування і далі світогляду, здавна і нині, стоять історичні і соціологічні проблеми. Це особливо яскраво позначається в свідомості української нації XIX i $\mathrm{XX}$ ст. Не навколо гносеологічних i не навколо природознавчих питань, як то було в мисленні Західної Свропи, але навколо питань історичної долі і правди кружляла українська духовність минулого і нашого сторіч. Тому Шевченко, Франко, Костомаров, Грушевський, Томашівський, Липинський - це творці і носії світогляду сучасного українства». До цієї цитати додає Кульчицький свій коментар, що в той спосіб український «сцієнтизм» пересувався в бік етичнорелігійних зацікавлень» [15, с. 92-93].

Надзвичайно важлива роль у виникненні, становленні й розвитку духовності українців належить вірі людини в Бога, у безсмертя духовних надбань нації, у незнищенність творінь людського духу, у безмежжя збагачення духовного життя людини. Тому в прецедентних висловах зафіксовано: Віра гори зсуває (двигає, рушить) (2, с. 45); Людина мислить, а Бог радить (2, с. 278); Людина крутить, а Бог розкручує (2, с. 278); Пошли, Боже, з неба, чого нам треба (2, с. 81); Дасть Бог день - дасть і пожиток (2, с. 82); Дасть Бог світ, дасть $i$ coвim (2, с. 270). Віра $є$ духовним надбанням особистості, вона допомагає формувати духовні чесноти задля примноження можливостей для творення добра. Така виняткова роль віри в духовному житті зумовлюється багатьма чинниками. Серед них варто виокремити ті моральні чесноти, покладені в основу віри у формі заповідей, настанов, сподівань, що є внутрішніми інстанціями, регуляторами духовного життя й моральної поведінки людини в соціумі. Звернімося до споконвічних істин, уміщених у паремійних кліше: Гріх не гріх, аби Бог простив (2, с. 78); Не краса красить, а розум (2, с. 76); Перед розумом і сила в 'яне (никне) (2, с. 239); Хвалися не рангом, а розумом (2, с. 76); Хто рано встає, тому Бог дає (у того 
все $\epsilon)$ (2, с. 138). 3 віри до найвищої сили постає і плекання довіри до ближнього, друга, доброзичливої, правдивої людини: Дай Боже 3 добрими людьми знатися (2, с. 232); Без вірного друга великая туга (2, с. 184); Вірний приятель - то найкращий скарб (2, с. 38); Вірну людину пізнаєш в лиху годину (2, с. 98); Добре братство краще за багатство (2, с. 38$)$.

Проте в народному світогляді відчутним відстежується дуалістичний підхід щодо оцінки духовних сутностей буття, а сам паремійний простір мови «становить свого роду континуум оцінок, рефлексій та інтуїцій, у якому висока віра поєднується 3 безвір'ям. Але і ті, й інші брали участь у генеруванні нових смислів, що мали стосунок до цінностей» [2, с. 228], передусім до власної активної життєвої позиції, духовних й інтелектуальних потенцій. Наприклад: Бога взивай, а руки прикладай (2, с. 35); Богом свідчить, а чортові душу запродав (2, с. 36); Богу молись, а сам стережись (2, с. 32); Боже, поможи, а ти, лежню, не лежи (2, с. 35); До Божого дару 3 чортовими ногами (2, с. 35); На Бога складайся, а роботи не иурайся (а розуму тримайся) (2, с. 35$)$; Не все до Бога, треба й до розуму свого (2, с. 35); Не лежи, небоже, то й Бог поможе (2, с. 35) і т. ін.

Виразним національно-культурним експонентом суспільних практик є духовний код. У низці наукових студій глибинне уявлення про етнічну культуру як семіотичну систему осмислюється за допомогою культурного коду. Це забезпечує опис передавання, переробки, зберігання інформації в межах знакових систем, якими є коди культури. Відтак важливим на сьогодні є дослідження питань кодифікації, й духовного коду зокрема, який становить моральні цінності й еталони, зафіксовані в мові. Духовність інтерпретовано крізь призму актуалізації духовного коду вітчизняної культури у прецедентних висловленнях.

Поняття культурного коду має низку визначень у сучасному мовознавстві. О. Абакумова, Ф. Бацевич, О. Березович, Д. Гудков, М. Ковшова, В. Красних, В. Маслова, О. Пальчевська, Ч. Ріллмор, 
Л. Савченко, О. Селіванова, А. Станкевіч, В. Телія, Г. Токарев та інші дослідники неодноразово зверталися до цієї проблематики. Вони дотримуються думки, що культура як полікодовий феномен «пронизана» культурними кодами, які вербалізуються як лінгвокультурні «згустки».

Під кодом культури розуміють «сітку», яку культура «накидає» на навколишній світ, членує, структурує й оцінює його [7, с. 232]. Відтак культурний код - це свого роду матриця, що визначає спосіб мислення й позначення світу. За В. Ужченком, культурні коди - це мережа членування, категоризації оцінок інтеріоризованого світу та внутрішнього досвіду людини, зумовлена культурою певного етносу й репрезентована в семіотичних системах природної мови [12, с. 457]. Код культури являє собою спосіб, яким культура членує, категоризує, структурує, оцінює світ, що оточує членів певної національної лінгвокультурної спільноти; сукупність знаків, смислів та їх комбінації, наявні в будь-якому предметі культури певної лінгвокультурної спільноти [6, с. 337].

Кількість культурних кодів незначна, a їх різноманітність зумовлена поєднанням і трансформацією культурних кодів, тому набір кодів для людини є універсальним явищем [7, с. 233]. Аналізуючи універсальні основні коди культури, співвідносні 3 архетипними уявленнями про Всесвіт, дослідники подають різні класифікації. Шість кодів культури виокремлює В. Красних: соматичний, просторовий, часовий, предметний, біоморфний, духовний [7, с. 233]. Особливої уваги заслуговує класифікація, що об'єднує такі коди культури: антропний, або власне людський; зооморфний; рослинний; природний; артефактно-предметний; духовно та / або релігійно-антропоморфний; релігійно-артефактний; часовий; просторовий; гастрономічний; архітектурний; кількісний; колірний; предметно-костюмний; тілесний, або соматичний (Д. Гудков, М. Ковшова, В. Телія).

Система кодів культури, як наголошують мовознавці, потребує упорядкування шляхом систематизації та грунтовного аналізу 
міжкодових метафоричних переходів. Між кодами культури немає чітких меж, вони дифузнопроникні (М. Ковшова, О. Селіванова, В. Телія). 3 огляду на таку особливість одна кодова система мовних позначень може переінтерпретовуватися знаками іншої. Наше зацікавлення становить духовний код культури, який лінгвалізує духовні цінності й еталони, зафіксовані в паремійному корпусі.

Під духовним кодом розуміємо аксіологізований код культури, що відображає моральні цінності й еталони та представлений основною векторною опозицією добро - зло. Саме за допомогою духовного коду з усією сукупністю моральних настанов і прескрипцій може бути представлений «дух народу», пізнаваний тільки через мову: «Мова $є$ ніби зовнішній вияв духу народів: мова народу $є$ його дух, i дух народу $\epsilon$ його мова, i важко уявити собі що-небудь більш тотожне» (В. фон Гумбольдт).

Поклик до гармонії почуттів, постійна потреба в самовдосконаленні, прагнення жити в духовних вимірах, відчуженість від надмірних турбот про матеріальні блага (гроші, кар’єру, славу, що можуть перетворитися на ненаситне, невгамовне джерело заздрощів та знищують у людині все людське i, зрештою, роблять і1і нещасливою) - усе це та подібне дає змогу людині розвивати в собі здатність не тільки відчувати велич людини як носія духовності, але й активно продукувати добро у власному щоденному житті, у взаєминах 3 оточенням: 3 рідними, друзями, близькими людьми. Український менталітет, що $\epsilon$ практичним, теоретичним $\mathrm{i}$ духовно-етичним досвідом нації, містить низку прецедентних висловлень, семантика яких грунтована на укорінених традиціях і світоглядних позиціях щодо всієї духовно-моральної сфери. Наприклад: Гарна пташка співом, а людина ділом (2, с. 135); Красна пташка своїм пір'ям, а людина своїм знанням (2, с. 76); На вітер надіятися - без мелива бути (2, с. 23); На злодієві шапка горить (2, с. 116); Срібло-злото тягне чоловіка в болото (2, с. 117); Хто гроші (золото) любить, той сам себе губить (2, с. 117) тощо. 
Духовні ідеали, визначаючи вищі сенси існування і спрямованість суспільного розвитку, становлять духовний код нації, виконують функцію духовного єднання і зміцнення суспільства. Система духовних цінностей і моральних норм є однією з важливих умов забезпечення i політичної, і соціальної стабільності суспільства. Проте нині прагнення багатьох представників соціуму до задоволення й користі на тлі уникнення будь-яких випробувань становить зміст новітніх уявлень про добро і щастя людини, утворюючи суть моралі задоволення егоїзму, духовний потенціал якої фіксуються зі знаком «мінус». Справжні цінності є абсолютними, вони формуються в нації протягом тривалого часу: Без пращі на калач не заробиш (2, с. 31); Терпінням і працею всього добудеш (2, с. 258); Треба нахилитися, аби (щзоб) з криниці води напитися (2, с. 31); Хто хоче збирати, мусить добре засівати (2, с. 31); Щастя не підкова - під ногами не знайдеш (2, с. 256) і т. ін.

Варто зауважити, що система цінностей сучасного молодого покоління спирається не лише на знання, а на світогляд, в основі якого лежать духовні й моральні орієнтири. Відмова від традиційних національних пріоритетів чи нехтування ними в українському суспільстві спричинили й актуалізували останніми роками низку загострених суспільних і соціокультурних чинників, як-от: духовну маргіналізацію, девальвацію моральних цінностей, етичний і правовий нігілізм, відсутність духовно-релігійної, культурної, громадянської самоідентифікації в значної частини українського соціуму та зростання на цьому тлі впливу псевдодуховних організацій i тоталітарних сект; розширення можливостей маніпулювання свідомістю на підставі руйнації старих ідеологічних ціннісних систем i штучного створення нових духовних i політичних кумирів, інфікування соціуму руйнівними й деструктивними ідеями насильства, ксенофобії, сепаратизму, радикального націоналізму, соціальної агресії, релігійного екстремізму й фанатизму; руйнування національних i традиційних цінностей українського народу; нав'язування масовій свідомості аморальних принципів і примітивних 
утилітарних смислів споживання; зростання аномальної залежності людини від інтернету і комп'ютерних технологій, що розцінюється як загроза свідомості; поширення соціальної апатії. Останнім часом спостерігається руйнування духовно-моральної спадкоємності та втрата традиційних родинних зв'язків [3, с. 6-7].

Відмова від багатовікових цінностей, зокрема i сімейних, розкриває наслідки й результати масової антидуховності та споживацької етики. Проте родинні міжособистісні стосунки повною мірою віддзеркалюють основні суспільні тенденції, адже сім'я як соціальна інституція завжди розвивалася паралельно й узгоджено 3 іншими суспільними інститутами.

Сфера сімейних стосунків, i власне процеси формування та становлення засад родини і шлюбу у світогляді українців, виразно репрезентовано в паремійному просторі мови. Осмислення в паремійних кліше принципів моделювання членами родини знань про світ, виділення в українській картині світу родинних змістовноінформаційних структур від давніх етапів поступу сімейної інституції до сьогодення дає змогу представити ціннісну царину людини в іiі найближчому родинному оточенні.

Концепт родина (рід, сім'я) є одним із ключових для української лінгвокультури, оскільки він виражає узагальнене знання і філософський досвід, пов'язаний із фрагментом дійсності, що наскрізь проймає все буття українського народу й людства загалом.

У паремійному просторі мови репрезентовано ідеальний варіант української родини: Тут я, тут $і$ жінка моя, тут $і$ мої діти, любо поглядіти (1, с. 183); Три вірні други: батько, мати та вірна жона (1, с. 183). Особливо цінувався в сім’ї лад, мир і спокій. За традиційними уявленнями українців, важливою є міцність і дружба в повноцінній родині, адже вона була основою комфорту та спокою: $B с я$ сім'я вмісті- так і душа на місті $(1$, с. 177); Горе з дітьми, горе й без дітей (2, с. 251); Нашуо й клад, коли в сім'ї лад (1, с. 177); Сім'я міцнагоре плаче; Хата з дітьми -базар, а без них-кладовище (2, с. 251). 


\section{СТРУКТУРА I СЕМАНТИКА МОВНИХ ОДИНИЦЬ}

У паремійних кліше батьки уособлюють сакральність світоглядних позицій кожної людини, що викликає найтепліші, найщиріші почуття. Батьків завжди цінують і поважають, у них питають порад, адже батько й мати бажають тільки добро власній дитині: Батьки глядять дочку до вінця, а чоловік - до кінця (1, с. 183). Батьки в будь-якому віці піклуються про своїх дітей, для них немає нічого важливішого від своїх спадкоємців: Як не стане, то батько дістане, як не буде, то мати добуде (1, с. 187).

В українському паремійному корпусі акцентовано увагу на тому, що батьків варто слухати, тому що вони мають значний життєвий досвід: Не послухаєш батька-матері, то навчить тебе лиха година (1, с. 186); Не слухав батька-матері, нехай люди научать $(1$, c. 186). Найстрашніша кара чекала на тих дітей, які не люблять або не поважають власних батьків. Хто батька-матір зневажає, той добра не знає (1, с. 187); Проклін батьків не на ліс сухий іде, а на голову дітей паде (1, с. 186).

Берегинею роду в українській духовній культурі завжди вважалася мати. Усі паремійні кліше розкривають красу й силу матері, адже вона дарує життя, надихає на добрі справи, віддає дітям усе, що має: тепло своєї душі, власне серце й безмежну любов.

У мовних одиницях на позначення родинної сфери й обрядовості найсакральніша лексема позначає функційний спектр жінки-матері: вона охороняла домашнє вогнище, продовжувала рід, виховувала дітей, а подекуди виконувала і функцію голови родини. Мати для людини - це втілення рідного краю, рідної домівки. Дорога до матері $\epsilon$ найважливішою серед інших доріг. Низка паремій засвідчує духовність і життєву мудрість матері, іiі здатність на самопожертву: На сонизі тепло, а коло матері добре (1, с. 188); Радаб мати для дітей небо прихилити та зорями вкрити (1, с. 189).

Мати - найцінніша цінність для кожної дитини, вона завжди оберігає своїх дітей від будь-яких негараздів протягом усього життя: Без матері $і$ сонце не гріє (1, с. 187); Матері ані купити, ані 
заслужити (1, с. 188); Жінка для світу, тещуа для привіту, а матінка рідна лучче всього світу (1, с. 180); Пташка радіє весні, а дитя мaтері (1, с. 189). Мати любить своїх дітей, незважаючи на те, який шлях обрали діти в житті, і причому стосовно кожної дитини материнські почуття є рівними й найтеплішими: Всяке дитя матері миле (1, с. 187); Матері кожної дитини жаль, бо якого пальця не вріж, то все болить (2, с. 109). Материнська любов безмежна, вона поряд 3 дитиною, де б та не була: Материнська молитва із дня моря nідіймає (1, с. 188); Любов матірня і на віддалі гріє (1, с. 188).

Не менш важливу роль у родинному культі відіграє батько. В українців він наділяється тими самими духовними рисами, що і мати, а, окрім цього, має значну фізичну силу. Діти люблять i поважають батька не менше від матері. Життя без нього також є дуже складним, адже батько підтримує й матеріально забезпечує життєдіяльність власних дітей: Своя хата - своя стріха, свій батько своя втіха (1, с. 186); Добре тому, хто має батька, бо в батька найтепліша хатка $(1$, с. 186$)$ тощо. В українській мовній свідомості закладене підгрунтя народної педагогіки, пов'язане з такою функцією батька, як виховування дітей шляхом покарання: Отець побатьківськи поб'є, по-батьківськи й помилує і т. ін.

Ціннісною основою родини як суспільної інституції є шлюб. 3 огляду на те, що шлюб брався на все життя, ставилися до вибору чоловіка або дружини дуже серйозно: Жінку бери здалека, корову купуй зблизька (1, с. 168); Заміж вийти - не дощцову годину перестояти (1, с. 168); I в лиху годину не кидай дружину (1, с. 178). Ціннісне наповнення родинних взаємин репрезентує і стосунки між чоловіком та дружиною. Низка паремійних кліше розкриває ставлення чоловіка до жінки й подає народну оцінку функційних можливостей чоловіка в сім’і: він є справжньою опорою та підтримкою для дружини: Без чоловіка - то так, як без голови (1, с. 184); Добрий чоловік надійніше кам'яного мосту (1, с. 184); Під добрим кущем трава зеленіє, за хорошим чоловіком жінка молодіє (1, с. 184). Серед 


\section{СТРУКТУРА I СЕМАНТИКА МОВНИХ ОДИНИЦЬ}

дослідженого ілюстративного матеріалу варто виокремити одиниці, в основі семантики яких лежить ставлення дружини до чоловіка, що також інтерпретується за основною віссю духовного коду добро - зло. Наприклад: 3 доброю дружиною горе - не горе, а щзастя - вдвоє (1, с. 178); Поможи, Боже, нежонатому, а жонатому й жінка поможе $(1$, с. 182$)$.

Стосункам у подружжі між чоловіком і жінкою присвячена низка паремій, у яких образ дружини інтерпретується як образ лихої, злої особи, що пояснювалося певними соціокультурними чинниками: почасти дівчину видавали заміж за нелюба. Крім того, тут віддзеркалюються певні народні екзистенції, i зокрема релігійноміфологічна свідомість, за якої щастя в родині залежало від непередбачуваної долі (Т. Владимирова). Тому і наявні прецедентні висловлення на зразок: Де лихая жінка в хаті, там добра не сподіватись (1, с. 180); Добра жінка мужеві своєму вінець, а зла кінець (1, с. 180); Жінка ледащз в хаті нінащо (1, с. 181).

Чоловіка та дружину завжди вважали неподільним цілим, тому, що не зробив би один із подружжя, це завжди поширювалося і на іншого: Муж і жона - одна сатана (1, с. 184); Куди голка, туди й нитка, куди чоловік, туди і жінка (1, с. 184). Як засвідчують наведені факти, екзистенційна й аксіологічна сутність подружжя вербалізується чи то крізь метафоризацію шлюбних стосунків за допомогою демонологічного образа духовного коду, чи то шляхом лінгвалізації фрагментів з господарсько-побутової сфери народного життя.

Українці не уявляли своєї родини без дітей. Так, завжди вважалося, що в родині повинно бути багато синів і дочок, бо вони зможуть допомогти й підтримати одне одного у скрутну годину. Неодноразово в паремійних кліше акцентовано, що з дітьми дуже складно жити, але без дітей життя нічого не варте: Без дітей тихо, а на старості лихо (1, с. 191); Діти - найбільша радість у світі (1, с. 191); Нема смерті без причини, нема щастя без дитини $(1$, с. 192). Батьки любили й цінували своїх дітей, адже для них дитина - найбільше щастя і цінність у житті. 
Батьки завжди намагалися кожного зі своїх дітей виховати гідно, закласти в них ті необхідні морально-етичні цінності, які потребуватимуть їм у житті: У добрих батьків добрі й діти (1, с. 189). До виховання дітей ставилися свідомо й відповідально, а не із сліпою батьківською любов'ю, щоб дитина, коли виросте, могла і далі сама адекватно жити в суспільстві: Батьківський хліб не навчить (2, с. 204); Не збирай сину худоби, а збери йому розум (1, с. 195); Розумному сину не збирай - сам наживе, а дурному не зоставляй - усе проживе (1, с. 195); Син хоч мій, але розум має свій (1, с. 195); Чужий син дурний - сміх, а свій син дурний - плач (1, с. 195). Відповідно, у народному світогляді закарбовано: діти $є$ відображенням чеснот i звичок батьків, і тому суспільна оцінка родини загалом відображає причинно-наслідкові зв'язки і здійснюється за життєдіяльністю кожного іiі складника: Від доброго коріння добрий $i$ пагонецьь відійде (2, с. 128); Дурна мати - дурні діти (2, с. 128); Зі злої (з поганоі) трави лихе й сіно (2, с. 128); Яка хата, такий тин, який батько, такий син (2, с. 128); Яка хатка, така й паніматка (2, с. 128); Яке дерево, такі ц̆ паростки (2, с. 128); Яке коріння, таке ци насіння (2, с. 128); Яке сім'ячко, таке й зіллячко (2, с. 128); Які ми самі, такі й наші сини (1, с. 196) тощо.

Отже, пареміологічне представлення духовної сфери та феномена сімейної традиції в Україні яскраво визначає склад, структуру, значення й семантичні зв'язки репрезентантів усіх складових родини як важливої національної цінності. Накладання засад функціонування мови на інтереси окремої особистості як соціальної істоти та цілої сім’і як етнічного, суспільного інституту сприяє перенесенню мовознавчих студій із статики в динамічний зріз суб'єкта пізнання у багатовіковій етноментальній спадщині українців.

Духовні цінності впливають на всі сфери суспільної та індивідуальної життєдіяльності. Значення їх у суспільстві виявляється в дії об’єктивних і суб'єктивних факторів, що впливають на характер мовного кодування, манеру і стиль комунікації. У процесі мовної 
взаємодії відбувається активізація всіх внутрішніх i зовнішніх рецепторів, які визначають глибинні шари культурної та соціальної взаємодії, впливають на формування суспільної поведінки. Так відбувається перекодування мовних параметрів на соціальні.

Духовний простір українства, як і простір загальнолюдської духовної культури, завжди містить у своїй побудові вертикаль, що розділяє сакральне й буденне, земне і небесне, верх і низ, добро і зло [14]. Однією $з$ поліфункціональних «аксіом свідомості» наших предків $\epsilon$ прагнення використовувати закладені в мовних знаках бінарні опозиції задля опису світу й регуляції людських стосунків (3. Коцюба, В. Красних, В. Телія та ін.). В. Красних пропонує використовувати такі опозиції культури, як добро - зло, добре - погано, верх - низ, плюс - мінус [7].

Універсальні опозиції морально-етичного підпорядкування добре - погано розкривають сутність духовності, адже добро і зло постають фундаментальними категоріями етики, і тому нерозривно взаємодіють між собою. Відтак у самих кліше знаходять «вираження смисложиттєві установки, орієнтири поведінки й уявлення, що сформувалися під впливом сакральної домінанти свідомості» [2, с. 217]. Філософський словник наголошує, що вони є нормативнооцінювальними категоріями моральної свідомості людини, 3 одного боку, позначають належне й морально-позитивне благо, а $з$ іншого, морально-негативне й негоже у вчинках людей [13, с. 108]. Оскільки поняття добро і зло виступають універсальною базою опозиції в царині етичного, то існують інші матричні протистояння у прецедентних висловленнях, які охоплюють широкий спектр людського буття. Основна бінарна опозиція дає змогу відстежити, що український народ дотримується десяти заповідей Божих, які $€$ складовими елементами національної віри й культури.

Підсумовуючи зазначене вище, додамо: особливості формування духовного коду зумовлені культурою певного етносу та його колективною свідомістю (мисленням, поведінкою, етичними та 
естетичними цінностями); виокремлюється в окрему складову суспільних практик; мовна компетенція презентує образне сприйняття як певний знаковий код; наявність семантичних маркерів дає змогу кваліфікувати й диференціювати одиниці системно організованого мовного коду. До основних маркерів духовного коду зараховуємо поляризатори опозиції та їх семантичні складники - добро і зло.

Духовність означає зосередження на людських потребах i звершеннях, визнання творчого потенціалу людства i цінності суб'єкта, утвердження поваги до гідності й розуму людини, iіi права на земне щастя, вільний вияв природних людських почуттів і здібностей. За допомогою паремійного простору мови якраз i може бути представлений «дух народу»: це система духовних законів, духовних цінностей, вироблених нацією в процесі іï формування.

Поняття «добро» і «зло» виступають універсальною опозицією в мовному вираженні духовності. Основною ознакою виявлення добра чи зла є оцінка. Вона завжди потребує наявності «плюса» чи «мінуса». Уся пареміологія побудована на протиставленні добра і зла. Добро розуміємо як сукупність належних кому-небудь речей, цінностей [4, с. 191]. У житті народу, його господарській діяльності мало велике значення, бо наживалося тяжкою працею, недарма мовиться: Добре тому, хто в своєму дому (1, с. 121); Добрий початок - половина діла $(2$, c. 146). 3 поняттям добро пов'язують усе позитивне в житті людей, що відповідає їхнім інтересам, бажанням і потребам: Усе добре впору (1, с. 68); Добре роби, добре буде; Все добре, щчо добре кінчається (1, с. 109) тощо.

Категорія зло характеризує що-небудь погане, недобре, протилежне категорії добро, проте вона не $\epsilon$ домінантною в паремійних аналогах. Споконвіку в релігійно-міфологічній свідомості народу зло уособлювалося у виразних демонологічних образах, у лихих силах природи, у недобрих вчинках людей. Про злих людей говорять: Злий зле $і$ думає $(1$, с. 265) У злому зле й сидить. Категорія зло в пареміологічному корпусі має широкий лінгвоментальний 
спектр - лихо, горе, біда, нещастя тощо. Наприклад: Біда біду знайде, коли ци сонце зайде (2, с. 26); Біда знайде, хоч $i$ в печі замажся (2, с. 26); Біда лихо породила (родить), а біду - чорт (чортова мати) (2, с. 26); До біди найдеться й прибідок (2, с. 26); До лиха та ще лихо (2, с. 26); Лихий чоловік, як хвороба: усе запакостить (1, с. 266); Лихо не вморить, так спотворить (2, с. 43).

Криза духовності крізь призму категорії зла в народній мовній свідомості простежується в усіх прецедентних висловленнях із зіставленням світоглядних феноменів добра i зла: Добро довго пам'ятається, а зло ще довще (2, с. 92); Добро (щастя) пушить, а лихо сушить (2, с. 26) тощо.

Парадокси суспільного буття українці оцінюють відповідно до традицій національної сміхової культури в пареміях на позначення категорії заперечення, наприклад: 3 бідою не знатися - $і$ щзастя не знайти (2, с. 171); I в нещуасті шастя буває (2, с. 171); Лихо не без добра (2, с. 171); Немає біди, щуоб не вийшли гаразди (2, с. 171); Немає злого, щуоб на добре не вийшло (2, с. 171); Щастя з нещастям в одних санях їзить (2, с. 171); Якби не нещастя, то не було б $і$ щзастя (2, с. 171); Як біда йде, то не треба підганяти (2, с. 26) тощо.

Задля того, аби адекватно розуміти цей навколишній світ $з$ його когнітивно-прагматичними установками і взаємозв'язками, людина оцінює його за допомогою категорій «правда» і «брехня». Правда - це те, що відповідає дійсності; певна сукупність достовірних відомостей про що-небудь. Правда - це істина, категорія, яка вічна [4, с. 476], наприклад: Правда у воді ( $i$ в морі) не втоне, у вогні не згорить (2, с. 220); Усе минеться, одна правда останеться (2, с. 220). Правда в екзистенційній картині світу українців, як і воля, сприймається як високоціннісна сутність, як правильність, упорядкованість, що грунтуються на справедливості, яка є запорукою щастя народу. Тому в мовному просторі української мови функціонує низка паремій на зразок: Гроші можуть багато, а правда - все (1, с. 45); Не любить правди, як пес мила (2, с. 220); Правда кривду переважить (2, с. 272); 
Правда очі коле (1, с. 46); Правда (сові соние) очі коле (2, с. 220); Правда, як олія, скрізь наверх спливе (вийде) (2, с. 220).

Бінарну позицію до категорії «правда» посідає категорія «брехня», що позначає свідоме й злісне викривлення дійсності на шкоду кому- або чому-небудь. Споконвіку народ засуджує брехню і брехунів: Брехня лиш раз їсть калачі (1, с. 280); В живі очі бреше (1, с. 281). Представлені категорії «правда» - «брехня» доводять, що для людини як соціальної істоти, що дотримується моральних норм і правил, національна правда i правдивість особистості є найважливішими національними цінностями українства. Саме їм відводиться роль семантичних маркерів духовного коду національної лінгвокультури.

Зазначимо, що дослідження духовності в українській пареміології $\epsilon$ досить актуальним напрямком сучасних мовознавчих студій, оскільки ії можемо вважати невичерпним джерелом вивчення духовного потенціалу українського етносу, у ній «відбито й актуалізовано основні життєві цінності нашого народу» (В. Калашник).

Прерогативою українства $є$ забезпечення та плекання духовного потенціалу нації, збереження і примноження національної культурної спадщини. Значення духовних цінностей у сучасному світі неухильно зростає, оскільки протистояти явищам бездуховності, зневаги до духовних надбань людства можна лише шляхом вдосконалення духовних і моральних потенцій суспільства, усвідомлення пріоритету загальнолюдських цінностей. Окреслені вище підходи поглиблюють уявлення про теоретичний $\mathrm{i}$ прикладний аспекти дослідження духовності, вивчення духовного коду як багатогранного суспільного феномену, що $є$ перспективним напрямком сучасних вітчизняних i зарубіжних суспільно-гуманітарних студій.

Отже, декодування мовного світогляду дає змогу інтерпретувати паремійний корпус, який віддзеркалює національну самосвідомість і перебіг культурної трансмісії. Цінності, зразки й норми поведінки, що виникають у результаті діяльності 3 освоєння світу, виступають 
водночас як елементи складного механізму регулювання соціального життя в різних типах суспільних практик. Найвищі щаблі загальнолюдської духовності, представлені в мовному вимірі, розкривають українську лінгвокультуру в контексті світової культурної традиції. Трансляція етнокультурної пам'яті народу в паремійних кліше і зростання національної свідомості, становлення знання та уявлення народу про минуле є важливими в осмисленні духовної сутності нації. Паремії як прецедентні феномени становлять собою духовну субстанцію, глибинні ментальні сутності, включені в систему етнокультурних духовних цінностей. Ключовими для розуміння цих семіотичних знаків $є$ комплекс моральних категорій та ідеалів, де сконцентровано зберігаються уявлення етносу про світ та відбилися не лише прагматичні установки, а й національний світогляд і загальне світосприйняття всіх носіїв національної мови.

\section{Література}

1. Боришевський М. Й. Соціально-психологічна сутність та генеза духовності особистості / М. Й. Боришевський // Проблеми загальної та педагогічної психології. К., 2009. - Т. XI. - Ч. 5. - С. 25-32.

2. Владимирова Т. Е. Концепт «СЧАСТЬЕ» в русской паремической картине бытия / Т. Е. Владимирова // Паремиология в дискурсе : Общие и прикладные вопросы паремиологии. Пословица в дискурсе и тексте. Пословица и языковая картина мира / Под ред. О. В. Ломакиной. - М. : ЛЕНАНД, 2015. - С. 214-231.

3. Єфрем, митрополит. Духовні цінності суспільства - культурно-етичні засади розвитку української нації / Митрополит Єфрем // Сучасний вимір православної культури : зб. матеріалів Четвертих міжнародних наукових Кирило-Мефодіївських читань. - Вип. 4. - Кривий Ріг, 2016. - С. 3-9.

4. Жайворонок В. В. Знаки української етнокультури : [словник-довідник] / В. В. Жайворонок. - К. : Довіра, 2006. - 703 с.

5. Калашник В. С. Студії з історії українського мовознавства та лінгвопоетики : зб. наукових праць / В. С. Калашник. - Х. : ХНУ імені В. Н. Каразіна, 2016. - 132 с.

6. Колоїз Ж. В. Українська пареміологія : [навчальний посібник] / Ж. В. Колоїз, Н. М. Малюга, Н. М. Шарманова ; за ред. Ж. В. Колоїз. - Кривий Ріг : КПІ ДВНЗ «КНУ», 2014. - $349 \mathrm{c}$.

7. Красных В. В. Этнопсихолингвистика и лингвокультурология : [курс лекций] / В. В. Красных. - М. : Гнозис, 2002. -284 с. 
8. Осіпов А. О. До методології аналізу феномену духовності / А. О. Осіпов // Актуальні проблеми духовності. - Кривий Ріг, 1995. - С. 31-37.

9. Савицька О. В. Етнопсихологія : [навчальний посібник] / О. В. Савицька, Л. М. Співак. - К. : Каравела, 2011. - 264 с.

10. Савченко Л. В. Феномен етнокодів духовної культури у фразеології української мови : етимологічний та етнолінгвістичний аспекти: [монографі] / Л. В. Савченко. - Сімферополь : Доля, 2013. - 600 с.

11. Сурмін Ю. Ціннісні процеси пострадянського суспільства : методологічний аспект / Ю. П. Сурмін // Збірник наукових праць НАДУ. - К. : Вид-во НАДУ. - 2003. Вип. 1. - С. 87-98.

12. Ужченко В. Д. Фразеологія сучасної української мови : [посібник] // В. Д. Ужченко, Д. В. Ужченко. - К. : Знання, 2007. - 494 с.

13. Философский энциклопедический словарь / Гл. ред. : Л. Ф. Ильичев, П. Н. Федосеев, С. М. Ковалев, В. Г. Панов. - М. : Сов. энциклопедия, 1983. - 840 с.

14. Целякова О. М. Духовність і ціннісні орієнтації студентської молоді України в трансформаційному суспільстві [Електронний ресурс]/ О. М. Целякова // Гуманітарний вісник ЗДІА. - 2009. - Вип. 38. - С. 222-233. - Режим доступу : http://essuir.sumdu.edu.ua

15. Янів В. Нариси до історії української етнопсихології / В. Янів / Упор. М. Шафовал. - [2-е вид., перероб. і доп.]. - К. : Знання, 2006. - 341 с.

\section{Використані джерела}

1. Українські прислів'я та приказки / Упорядн. С. Мишанич, М. Пазяк ; передм. М. Пазяка. - К. : Дніпро, 1984. - 389 с.

2. Російсько-український тлумачний словник паремій / Ж. В. Колоїз, 3. П. Бакум, Л. А. Білоконенко, Т. І. Вавринюк, Н. М. Малюга, Н. М. Шарманова ; за ред. проф. Ж. В. Колоїз. - Кривий Ріг : ФОП Маринченко С. В., 2016. - 454 с.

Стаття надійшла до редакиії 15.10 .2016 р. 